\title{
Transformation of Nutrients and Organic Matter in Vermicomposting of Sewage Sludge and Kitchen Wastes
}

\author{
Egge Haiba ${ }^{1}$, Mari Ivask ${ }^{1}$, Lilian Olle ${ }^{2}$, Jane Peda ${ }^{1}$, Annely Kuu ${ }^{1}$, Sander Kutti ${ }^{1} \&$ Lembit Nei $^{1,3}$ \\ ${ }^{1}$ Tartu College, Tallinn University of Technology, Puiestee 78, Tartu, Estonia \\ ${ }^{2}$ Estonian Agricultural Registers and Information Board, Narva mnt 3, Tartu, Estonia \\ ${ }^{3}$ Department of Environmental Science, Policy and Geography, University of South Florida St. Petersburg, 140 \\ 7th Ave. S., St. Petersburg, FL 33701, USA \\ Correspondence: Lembit Nei, Tartu College, Tallinn University of Technology, Puiestee 78, 51008 Tartu, \\ Estonia; Department of Environmental Science, Policy and Geography, University of South Florida St. \\ Petersburg, 140 7th Ave. S., St. Petersburg, FL 33701, USA. E-mail: lembit.nei@ttu.ee
}

Received: December 5, $2013 \quad$ Accepted: December 26, $2013 \quad$ Online Published: January 15, 2014
$\begin{aligned} & \text { doi:10.5539/jas.v6n2p114 } \\ & \text { URL: http://dx.doi.org/10.5539/jas.v6n2p114 }\end{aligned}$

\begin{abstract}
This study was conducted to compare how the nutrients and organic matter content in household kitchen wastes and sewage sludge transform in 120-days vermicomposting experiment. The concentrations of nitrogen, phosphorous and potassium increased during the experiment. The dry matter content of the composts decreased and the value of $\mathrm{pH}$ in the case of kitchen wastes increased and for sewage sludge vermicompost it remained almost unchanged. The amounts of organic matter and nutrients decreased to half of the initial masses, but the concentrations of nutrients increased remarkably both in kitchen wastes and in sewage sludge and sawdust mixtures as a result of vermicomposting. Vermicompost made from kitchen wastes contained $3.3 \%$ total nitrogen, $0.7 \%$ total phosphorous and $5.8 \%$ potassium. In the case of the vermicompost made from sewage sludge and sawdust the corresponding indicators were: $2.4 \%$ total nitrogen, $0.2 \%$ total phosphorous and $0.3 \%$ potassium. Small-scale vermicomposting of both household kitchen wastes and sewage sludge turned to be efficient.
\end{abstract}

Keywords: Dendrobaena veneta, Eisenia fetida, vermicomposting

\section{Introduction}

Composting of organic wastes is a traditional cost-effective way to reduce wastes and to reuse organic matter (Tremier, de Guardia, Massiani, Paul, \& Martel, 2005; Suthar \& Singh, 2008; Lillenberg et al., 2010). An attractive alternative to thermophilic composting is the application of certain epigeic earthworm species (Edwards, Subler, \& Arancon, 2011; Ivask, Olle, \& Nei, 2013). Substrate aeration, mixing, grinding, fragmentation, enzymatic digestion and also microbial decomposition take place in the intestines of earthworms (Sharma, Pradham, Satya, \& Vasudevan, 2005; Adi \& Noor, 2009). Organic matter decomposes to mineral compounds, carbon dioxide and water. Under aerobic conditions microbial and faunal decomposers participate in this process. Vermicompost is especially interesting as an organic fertilizer because it is characterized by a high content of plant available nutrients (Edwards \& Arancon, 2004; Dominguez, 2004; Adi \& Noor, 2009).

Several authors (Dominguez, 2004; Kaushik \& Garg, 2004; Edwards et al., 2011; Maksimova, 2011) have pointed out that earthworms are the key organisms in decomposing organic matter and transforming nutrients. Dominguez (2004) has described vermicomposting as a decomposition process involving interactions between earthworms and microorganisms. Microorganisms are responsible for the biochemical degradation of organic matter, while earthworms are the crucial drivers of the process, fragmenting and conditioning the substrate, increasing its surface area and altering the biological activity of the media (Edwards \& Arancon, 2004). Earthworms are acting as a kind of ecological engineer that consumes organic wastes, breaks them down into very small particles and decreases the C:N ratio (Edwards et al., 2011). The species most commonly used for breaking down organic wastes are Eisenia fetida (Savigny, 1826) and Dendrobaena veneta (Rosa, 1886). The reasons why Eisenia fetida or Dendrobaena veneta species are preferred in vermicomposting are that they tolerate a wide range of temperatures and they are readily handled, and in mixed species cultures they usually 
become dominant (Edwards \& Arancon, 2004). In Estonia, Latvia and Lithuania Eisenia fetida is one of the native earthworm species inhabiting manure and compost piles.

Several studies have demonstrated the ability of some earthworm species to consume a wide range of organic wastes such as sewage sludge, animal dung, crop residues and industrial effuse (Chan \& Griffiths, 1988; Hartenstein \& Bisesi, 1989; Edwards, 1998). The vermicompost has more available nutrients per kg weight than the organic substrate from which it is produced (Buchanan, Russell, \& Block, 1988). The biological activity of earthworms provides nutrient rich vermicompost for plant growth, thus facilitating the transfer of nutrients to plants (Ismail, 2000).

Recently a detailed study performed by Yousefi, Younesi and Ghasempoury (2013) resulted in that the mixture of one waste high in carbon and low in nitrogen (sawdust) with another waste that is high in nitrogen (municipal solid waste, MSW) makes it possible to obtain an optimum C:N ratio for composting, increase water preservation and improve the final quality of the compost product. The composting piles with sawdust required shorter composting periods than those without any sawdust.

Small-scale composting is becoming increasingly popular in households. Systems located outdoors can handle a larger amount of household waste but these are influenced by extremes in weather (Sherman \& Appelhof, 2011). When operating at low ambient temperatures the vermicomposting systems have very low rates of earthworm reproduction (Frederickson \& Howell, 2003). Because of this vermitechnology is not widely used in Nordic countries. With the aim of overcoming this disadvantage, the current study was to evaluate how earthworms Eisenia fetida and Dendrobaena veneta are able to recycle household organic wastes in small-scale composting experiments under boreal climatic conditions.

\section{Materials and Methods}

The experiment was conducted in a non-heated room. The duration of composting was 120 days. Earthworms Eisenia fetida and Dendrobaena veneta were used in vermicomposting experiments performed in non-transparent plastic containers. The temperature of the composting material was measured during the whole experiment.

The experiments with kitchen wastes were performed as follows: the containers were filled with $0.5 \mathrm{~kg}$ of mineral soil, $0.5 \mathrm{~kg}$ of earthworms and $0.5 \mathrm{~kg}$ of kitchen wastes. The kitchen wastes included a mix from a family kitchen: fruits, vegetables and plants (fresh or boiled); coffee grounds and teabags including paper; eggshells, chopped up; kitchen paper; milk and meat in small amounts. $0.5-1.0 \mathrm{~kg}$ of the mixed kitchen waste was added to the boxes once per week - 18 times during the experiment. The total amount of added wastes was $10-15 \mathrm{~kg}$.

In the experiments with sewage sludge the mixtures were made from $6 \mathrm{~kg}$ of sawdust, $4 \mathrm{~kg}$ of sewage sludge and $0.5 \mathrm{~kg}$ of earthworms. The matter was mixed periodically after every 5-7 days, so providing both sufficient aeration and homogenization.

The chemical composition of the studied wastes was analyzed in the beginning and in the end of the experiment. All chemical analyses were performed by the Plant Biochemistry Laboratory of Estonian University of Life Sciences. The methodologies of the analyses are presented in detail in the Official Methods of Analysis (1990). The following applications were carried out: moisture (gravimetric), $\mathrm{pH}_{\mathrm{KCl}}$, total nitrogen (TotN, by the Kjeldahl method), total phosphorus (TotP), and potassium (flame photometric method). The content of organic matter was determined by loss on ignition method according to Schulte, 1995.

Data analysis was performed by the program STATISTICA 8.0. The corresponding differences between mean values of parameters were compared using the ANOVA one-way method.

\section{Results}

The results of the current study, allowing the comparison of two sets of vermicomposts, made from different types of household wastes, are presented in Table 1. The mean organic matter content in kitchen wastes added during the experiment was $78 \%$. In the final product - compost - the relevant value had decreased to $49 \%$. The dry matter content of the kitchen wastes was $18 \%$ and it remained the same with the accuracy of $\pm 1 \%$ in the final compost (after 120 days from the beginning of the experiment, Table 1). At the same time, the values of $\mathrm{pH}$ and the concentrations of TotN, TotP and potassium increased. The $\mathrm{pH}$ of compost increased from 5.2 to 8.3 at the end of the experiment. The contents of nutrients increased as follows: TotN from $1.8 \%$ to $3.3 \%$, from TotP from 0.2 to $0.7 \%$ of and $\mathrm{K}$ from 1.9 to $5.8 \%$ of. During the first two days the temperature increased to $18^{\circ} \mathrm{C}$ and afterwards remained stable during the course of the experiment. 
In the experiments with sewage sludge and sawdust mixture the following results were obtained: the content of organic matter was $54 \%$, dry matter $-17 \%$, TotN $-2.4 \%$, Tot $\mathrm{P}-0.2 \%$ and potassium $-0.3 \%$. The $\mathrm{pH}$ of the compost was 6.6. For the comparison, the relevant indicators for typical sewage sludge are also given in Table 1 .

Table 1. The composition of kitchen wastes, sewage sludge, and their vermicomposts

\begin{tabular}{lcccccc}
\hline & $\begin{array}{c}\text { Organic } \\
\text { matter (\%) }\end{array}$ & $\begin{array}{c}\text { Moisture } \\
(\%)\end{array}$ & $\mathrm{pH}$ & $\begin{array}{c}\text { Total N } \\
(\%)\end{array}$ & $\begin{array}{c}\text { Total P } \\
(\%)\end{array}$ & $\begin{array}{c}\text { Potassium } \\
(\%)\end{array}$ \\
\hline kitchen wastes & $77.9 \pm 1.3$ & $82.4 \pm 0.9$ & $5.2 \pm 0.1$ & $1.8 \pm 0.1$ & $0.2 \pm 0.0$ & $1.9 \pm 0.1$ \\
vermicompost (kitchen wastes)* $^{*}$ & $48.8 \pm 1.1$ & $83.5 \pm 0.3$ & $8.3 \pm 0.2$ & $3.3 \pm 0.1$ & $0.7 \pm 0.0$ & $5.8 \pm 0.3$ \\
sewage sludge** $_{\text {Vermicompost (sewage sludge)* }}$ & $63.3 \pm 6.4$ & $74.2 \pm 1.1$ & $7.4 \pm 1.0$ & $2.2 \pm 1.6$ & $1.1 \pm 0.5$ & $2.1 \pm 0.4$ \\
\hline
\end{tabular}

*120 days after starting the experiment; **the results were provided by AS Tallinna Vesi (Tallinn Water Ltd.).

\section{Discussion}

In our experiment with kitchen wastes the concentrations of nitrogen, phosphorous and potassium increased as a result of vermicomposting. Several authors (Garg, Gupta, \& Santosh, 2006; Garg, Suthar, \& Yadav, 2012; Bharadwaj, 2010) have published similar results, except the dynamics of $\mathrm{pH}$, which decreased in these studies. In these comparable studies the initial $\mathrm{pH}$ value was higher than in our experiment, but the final $\mathrm{pH}$ values of the composts became almost equal. This can be explained by the earthworms' ability to adapt the habitat by altering the $\mathrm{pH}$ of the substrate to the optimal level with the aim of surviving the population (Dominguez, 2004). The sufficient rise in the values of TotN, TotP and $\mathrm{K}$ in the vermicompost indicates that there was an enhanced mineralization of these elements due to microbial and enzyme activity in the gut of the earthworms, although the increase in concentrations was lower in comparison with some published results obtained from warmer climate regions (Parthasarathi \& Ranganathan, 2000; Garg et al., 2006).

It has been reported that earthworm casts contain more carbon and nitrogen than non-ingested soil (Fragoso, Barois, Gonzalez, Artega, \& Patron, 1993). This indicates that nitrogen is localized in worm castings. The percentage losses of carbon and gains in nitrogen per dry weight during vermicomposting are in agreement with observations made by Vinceslas-Apka and Loquet (1997), who described substantial losses in organic carbon and increases in TotN contents in vermicomposts after 10 months. In addition to the increased content of nitrogen per dry weight, there is also an extra addition of mucus, nitrogenous excretory substances, growth stimulating hormones and enzymes from earthworms in worm-worked bedding (Bhadauria \& Ramakrishnan, 1996).

The increase in TotP in our experiment from 0.2 to $0.7 \%$ is considerable. Similar results have been published by Ghosh, Chattopadhyay, and Baral (1999) and Garg et al. (2006), who concluded that earthworms are efficient in mineralizing organic phosphorous. This is probably due to mineralization and mobilization of phosphorus as a result of enhanced phosphatase activity in earthworm casts, burrows and guts (Brown \& Doube, 2004). The microbial community influences the level of available potassium - the potassium content was almost three times higher in the end of the experiment. This result is in agreement with the results obtained by other authors (Garg et al., 2006).

The moisture content of kitchen wastes is usually high. In our study, the moisture content of the compost in the end of the period was $84 \%$, which is the optimal value for Eisenia fetida according to Dominguez (2004). The results obtained in the end of composting were compared with quality criteria for vermicompost, proposed by Edwards et al. (2011); all the relevant values (except the moisture content) corresponded to these criteria (Table 1).

In the experiments with sewage sludge and sawdust mixture comparable results were obtained (see Table 1). Only the content of minerals and TotP of the final product were below the values that have been recommended by Edwards et al. (2011). There is no doubt that these (essential) differences resulted from the additions of sawdust. The $\mathrm{pH}$ of the compost was 6.6 , being lower than in the case of the vermicompost made from kitchen wastes. This is in agreement with the results obtained by Yousefi et al. (2013): in this study sawdust admixtures also produced lowering of $\mathrm{pH}$ in final products. 


\section{Conclusion}

Vermicomposting technology is a simple and environmentally friendly biological treatment of wastes. As a result of the current work we have proven the applicability and efficiency of using earthworms Eisenia fetida and Dendrobaena veneta in a small-scale vermicomposting of household organic residues in the countries with the climate comparable to Estonia.

\section{References}

Adi, A. J., \& Noor, Z. M. (2009). Waste recycling: Utilization of coffee grounds and kitchen waste in $\begin{array}{llll}\text { vermicomposting. } & \text { Bioresource } & \text { Technology, } & \text { 100(2), }\end{array}$ http://dx.doi.org/10.1016/j.biortech.2008.07.024

Bhadauria, T., \& Ramakrishnan, P. S. (1996). Role of earthworms in nitrogen cycling during the cropping phase of shifting agriculture (Jhum) in north-east India. Biology and Fertility of Soils, 22(4), 350-354. http://dx.doi.org/10.1007/BF00334582

Brown, G. G., \& Doube, B. M. (2004). Functional Interactions between earthworms, microorganisms, organic matter and plants. In C. A. Edwards (Ed.), Earthworm Ecology (pp. 213-239). CRC Press LLC, Boca Raton.

Buchanan, A. M. A., Russell, A. G. A., \& Block, S. D. (1988). Chemical characterization and nitrogen mineralization potentials of vermicompost derived from differing organic wastes. In C. A. Edwards, \& E. F. Neuhauser (Eds.), Earthworms in Waste and Environmental Management (pp. 231-239). SPB Academic Publishing PV, The Hague.

Chan, P. L. S., \& Griffits, D. A. (1988). The vermicomposting of pre-treated pig manure. Biological Wastes, 24(1), 57-69. http://dx.doi.org/10.1016/0269-7483(88)90027-4

Dominguez, J. (2004). State-of-the Art and New Perspectives on Vermicomposting Research, In C. A. Edwards (Ed.), Earthworm Ecology (pp. 401-424). CRC Press LLC, Boca Raton.

Edwards, C. A. (1998). The use of earthworms in the breakdown and management of organic wastes. In: Edwards, C.A. (Ed.), Earthworm Ecology (pp. 327-354). CRC Press, FL: Boca Raton.

Edwards, C. A., \& Arancon, N. Q. (2004). The use of earthworms in the Breakdown of Organic Wastes to Produce Vermicomposts and Animal Feed Protein. In C. A. Edwards (Ed.), Earthworm Ecology (pp. 345-399). CRC Press LLC, Boca Raton.

Edwards, C. A., Subler, S., \& Arancon, N. Q. (2011). Quality Criteria for Vermicomposts. In C. A. Edwards, N. Q Arancon, \& R. Sherman (Eds.), Vermiculture Technology. Earthworms, organic wastes and environmental management (pp. 287-301). CRC Press, Boca Raton.

Fragoso, C., Barois, I., Gonzalez, C., Artega, C., \& Patron, J. C. (1993). Relationship between earthworms and soil organic matter levels in natural and managed ecosystems in the Mexican tropics. In: K. Mulongoy, \& R. Merckx, (Eds.). Soil Organic Matter dynamics and Sustainability of Tropical Agriculture (pp. 231-239). A Wiley-Sayce Co. Publication, New York.

Frederickson, J., \& Howell, G. (2003). Large-scale vermicomposting: emission of nitrous oxide and effects of temperature on earthworm populations: The 7th international symposium on earthworm ecology, Cardiff, Wales, 2002. Pedobiologia, 47(5-6), 724-730. http://dx.doi.org/10.1078/0031-4056-00250

Garg, P., Gupta, A., \& Santosh, S. (2006). Vermicomposting of different types of waste using Eisenia foetida: A $\begin{array}{lllll}\text { comparative study. } & \text { Bioresource } & \text { Technology, } & \text { 97(3), } & \text { 391-395. }\end{array}$ http://dx.doi.org/10.1016/j.biortech.2005.03.009

Garg, V. K., Suthar, S., \& Yadav, A. (2012). Management of food industry waste employing vermicomposting technology. Bioresource Technology, 126, 437-443. http://dx.doi.org/10.1016/j.biortech.2011.11.116

Ghosh, M., Chattopadhyay, G. N., \& Baral, K. (1999). Transformation of phosphorus during vermicomposting. Bioresource Technology, 69(2), 149-154. http://dx.doi.org/10.1016/S0960-8524(99)80001-7

Hartenstein, R., \& Bisesi, M. S. (1989). Use of earthworm biotechnology for the management of effluents from intensively housed livestock. Outlook Agriculture, 18(2), 72-76.

Ismail, S. A. (2000). Organic waste management. In: Technology Appreciation Programme on Evaluation of Biotechnological Approaches to Waste Management held on 26th October 2000 (pp. 28-30). Industrial Assotiation-Ship of IIT, Madras. 
Ivask, M., Olle, L., \& Nei, L. (2013). Domestic organic waste treatment through vermitechnology. Waste Management \& Research, 31(8), 878. http://dx.doi.org/10.1177/0734242X11403798

Kaushik, P., \& Garg, V. K. (2004). Dynamics of biological and chemical parameteres during vermicomposting of solid textile mill sludge mixed with cow dung and agricultural residues. Bioresource Technology, 94(2), 203-209. http://dx.doi.org/10.1016/j.biortech.2003.10.033

Lillenberg, M., Yurchenko, S., Kipper, K., Herodes, K., Pihl, V., Lohmus, R., .. Nei, L. (2010). Presence of fluoroquinolones and sulfonamides in urban sewage sludge and their degradation as a result of composting. International Journal of Environmental Science and Technology, 7(82), 307-312. Retrieved from http://www.ijest.org/jufile?c2hvd1BERj00MDE=\&ob=1ac5df118387d2eb0fb46ab4044301 c6\&fileName=f ull_text.pdf

Maksimova, S. (2011). Progress in Vermicomposting in Belarus, Russia and Ukraine, In: C.A. Edwards, N.Q Arancon, \& R. Sherman, (Eds.), Vermiculture Technology. Earthworms, organic wastes and environmental management (pp. 565-578). CRC Press, Boca Raton.

Official Methods of Analysis. (1990). AOAC $15^{\text {th }}$ Edition. K. Helrich (Ed.), Association of Official Analytical Chemists, Arlington, Virginia, Volume 2.

Parthasarathi, K., \& Ranganathan, L. S. (2000). Aging effect on enzyme activities in pressmud vermicasts of Lampito mauritii (Kinberg) and Eudrilus eugeniae (Kinberg). Biology and Fertility of Soils, 30(3), 347-350. http://dx.doi.org/10.1007/s003740050014

Schulte, E. E. (1995). Recommended Soil Organic Matter Tests. In J. T. Sims, \& A. Wolf (Eds.), Recommended Soil Testing Procedures for the Northeastern United States (pp. 47-56). Northeast Regional Bulletin 493. Newark, DE: Agricultural Experiment Station, University of Delaware.

Sharma, S., Pradham, K., Satya, S., \& Vasudevan, P. (2005). Potentiality of earthworms for waste management and in other use - A Review. The Journal of American Science, 1(1), 4-16. Retrieved from http://www.jofamericanscience.org/journals/am-sci/0101/02-sharma.pdf

Sherman, R., \& Appelhof, M. (2011). Small-Scale School and Domestic Vermicomposting Systems. In C. A. Edwards, N. Q. Arancon, \& R. Sherman (Eds.), Vermiculture Technology. Earthworms, organic wastes and environmental management (pp. 67-78). CRC Press, Boca Raton.

Suthar, S., \& Singh, S. (2008). Vermicomposting of domestic waste by using two epigeic earthworms (Perionyx excavatus and Perionyx sansibaricus). International Journal of Environmental Science and Technology, 5(1), 99-106. Retrieved from http://www.ijest.org/?_action=articleInfo\&article=197

Tremier, A., de Guardia, A., Massiani, C., Paul, E., \& Martel, J. L. (2005). A respirometric method for characterising the organic composition and biodegradation kinetics and the temperature influence on the biodegradation kinetics, for a mixture of sludge and bulking agent to be co-composted. Bioresource Technology, 96(2), 169-180. http://dx.doi.org/10.1016/j.biortech.2004.05.005

Vinceslas-Apka, M., \& Loquet, M. (1997). Organic matter transformations in lignocellulosic waste products composted or vermicomposted (Eisenia fetida andrei): chemical analysis and 13C CPMAS NMR $\begin{array}{lllll}\text { spectroscopy. Soil Biology } \quad \text { \& } & \text { Biochemistry, } & \text { 29(3), }\end{array}$ http://dx.doi.org/10.1016/S0038-0717(96)00201-5

Yousefi, J., Younesi, H., \& Ghasempoury, S. M. (2013). Co-composting of municipal solid waste with sawdust: improving compost quality. Clean - Soil Air Water, 41(2), 185-194. http://dx.doi.org/10.1002/clen.201100315

\section{Copyrights}

Copyright for this article is retained by the author(s), with first publication rights granted to the journal.

This is an open-access article distributed under the terms and conditions of the Creative Commons Attribution license (http://creativecommons.org/licenses/by/3.0/). 